\title{
Control and Monitoring Automatic Floodgate Based on NodeMCU and IOT with Fuzzy Logic Testing
}

\author{
Satriya Ramahdika Utama ${ }^{1 *}$, Ahmad Firdausi ${ }^{2}$, Galang P. N. Hakim ${ }^{3}$ \\ Department of Electrical Engineering, Universitas Mercu Buana, Jakarta, Indonesia \\ Email: 'rhamadika@gmail.com, ${ }^{2}$ ahmad.firdausi @ mercubuana.ac.id, ${ }^{3}$ galang.persada@ mercubuana.ac.id \\ *Corresponding Author
}

\begin{abstract}
Flood is still a problem that always been a major obstacle in several big cities in Indonesia such as DKI Jakarta. If the rainfall so high and river can be accommodating the rainfall, there will be flooding. So that river water doesn't overflow, it is necessary to make a floodgate in the river flow. One of the previous studies that has been carried out regarding the control and monitoring of water dam gates is researched by Fahruddin. 2014 from the Faculty of Science and Technology, Makassar State Islamic University: Describes the design of a device capable of monitoring the height of water activity in the reservoir and controlling the floodgates automatically according to the height of water activity. The research that the writer is currently carrying out is the design method which consists of a series of sensors, NodeMCU microcontrollers, and Stepper Motors. The workflow of this system is when the water rises or falls, it sends a signal to the sensor. And then the signal will be input for the microcontroller which is then processed to turn on the motor, so that it can open or close the floodgates, and send information to the indicator screen and Telegram application. After the experiment is carried out, it can be said that the system can work properly, namely when the ultrasonic sensor experiment, it was found that the sensor has been sent an output signal that was in accordance with the water level in actual condition. Based on testing using the fuzzy method, it was found that opening value at the floodgate obtained during the test had an average accuracy rate of $91 \%$ with an error difference of $9 \%$.
\end{abstract}

Keywords-Floodgate, Water Level, Ultrasonic Sensor, Microcontroller, NodeMCU, Rainfall, Fuzzy Logic

\section{INTRODUCTION}

Rainy season still haunts the citizens of the capital. In Indonesia, the rainy season occurs for five to six months. During on the period, Indonesia region have a potential to rain with varying rainfall [1]. During extreme weather events transport infrastructure can be directly or indirectly damaged, posing a threat to human safety, and causing significant disruption and associated economic and social impacts [2]. Flooding, especially as a result of intense precipitation, is the predominant cause of weather-related disruption to the transport sector [3], [4]. If the rainfall is very high, and the river cannot accommodate this rainfall, there will be flooding.

To regulate river water discharge so as not to overflow and causing flooding, it is necessary to make a floodgate in the river flow, because the floodgates in urban river flows have an important function, because that is one of the instruments for controlling river water and become one of the elements of flood control [5].
Optimal flood management in complex river networks is then a way to reduce flood hazard, at a relatively low cost compared to structural measures [6]. The advancement of technology had many influences in aspects of life, especially in the field of urban planning [7]. In modern urban planning, a good control system is needed to carry out and support the urban planning process [8]. Uncontrolled water level can make a reservoir overflow due to lack of information to the flood gate supervisor, this is due to the current flood gate control system [9].

Therefore, manual floodgate control is less effective for controlling river water flow [10], because it was only based on monitoring the water level, therefore the ineffective control of river floodgates is still a major factor in the occurrence of flooding [11]. Based on the above problems, it can be concluded that the relevant agencies need to prepare a monitoring device as well as control the river floodgates automatically.

At the present time now is not impossible to carry out control and monitoring by remote, as the NodeMCU microcontroller can be programmed so that it can monitoring and controlling the floodgates automatically, so that is the background for author to design and build a monitoring and controlling automatic floodgate based microcontroller with Fuzzy logic testing methods.

\section{METHOD}

In this research, the Fuzzy system is used control floodgate, so that it can be seen whether the device designed is in accordance with mathematical calculations or not. Fuzzy algorithm was proposed by Lotfi Zadeh In 1965 [12], [13]. This algorithm is developed to find solution based on approximate reasoning, that is neither very imprecise nor very precise [14]. From 1965 until now a lot of new fuzzy methods has been develop such as FTS [15], [16], FMEA [17], ANFIS [18], TOPSIS [19]. This fuzzy method not only control problems but also other real world problems [20][22], but also decision making [23], supplier selection [24], [25], traffic light [26], Risk and Fault analysis [27]-[29], forecasting [30], and others [31]-[34].

In this fuzzy method design, there is a membership function, where the membership function is a range of values to represent the linguistic variables that are owned so that these variables will determine the outcome of the 
decision. In this tool there are 2 fuzzy variables, namely the water level and the increase of floodgates.

TABLE I. FUZZY VARIABLE

\begin{tabular}{|c|c|c|}
\hline Function & Variable & Universal Set \\
\hline Input & Water Level & $5 \mathrm{~cm}-13 \mathrm{~cm}$ \\
\hline Output & Increase of the floodgates & $0 \mathrm{~cm}-5 \mathrm{~cm}$ \\
\hline
\end{tabular}

Variable of water level has 9 sets: $5 \mathrm{~cm}, 6 \mathrm{~cm}, 7 \mathrm{~cm}, 8 \mathrm{~cm}$, $9 \mathrm{~cm}, 10 \mathrm{~cm}, 11 \mathrm{~cm}, 12 \mathrm{~cm}$, and $13 \mathrm{~cm}$. Meanwhile, the increase variable in the floodgate opening has 3 variables: the increase with a range of $0 \mathrm{~cm}<1 \mathrm{~cm}$, a range of $1 \mathrm{~cm}$ $<3 \mathrm{~cm}$, and a range of $3 \mathrm{~cm}<5 \mathrm{~cm}$.

Based on the input and output values in Table 1, the fuzzy rules can be set which will be programmed as shown in the Table 2 and Fig. 1.

\section{TABLE II. FUZZY RULES}

\begin{tabular}{|c|c|c|c|}
\hline \multicolumn{4}{|c|}{ RULES } \\
\hline STATUS & STANDBY & ALERT & DANGER \\
\hline Water Level & $7 \mathrm{~cm}$ & $10 \mathrm{~cm}$ & $13 \mathrm{~cm}$ \\
\hline Increase of the floodgate & $1 \mathrm{~cm}$ & $3 \mathrm{~cm}$ & $5 \mathrm{~cm}$ \\
\hline
\end{tabular}

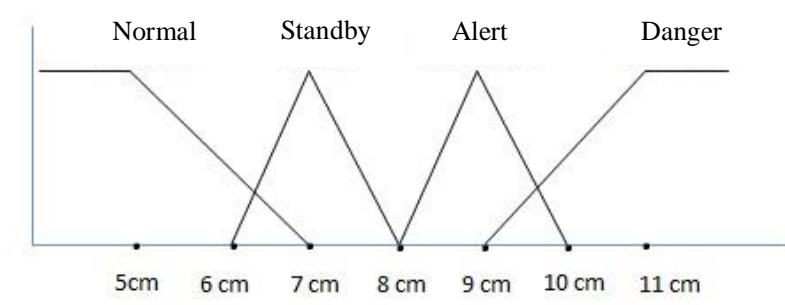

Fig. 1. Water Level Membership Function

Then to test this prototype are using the Weighted Average formula as follows:

$$
z=\frac{\sum_{i}^{N} w_{i} z_{i}}{w_{i}}
$$

For example, calculating the water level input $8 \mathrm{~cm}$ using the Weighted Average formula as follow. Calculating the value $w_{i}$ :

$$
\begin{gathered}
w_{i} \text { alert }[8]=\frac{10-8}{10-7}=0.6667 \\
w_{i} \text { standby }[8]=\frac{8-7}{10-7}-0.3333
\end{gathered}
$$

The " $Z$ " value is:

$$
\begin{gathered}
Z=\frac{W_{i} \text { alert }(1)+W_{i} \text { standby }(3)}{W_{i} \text { alert }+W_{i} \text { standby }} \\
Z=\frac{0.6667(1)+0.3333(3)}{0.6667+0.3333} \\
Z=1.6667
\end{gathered}
$$

So that the value of the increase in the floodgate if the water level in the tank reaches $8 \mathrm{~cm}$ when calculated using the weighted average formula is $1.6667 \mathrm{~cm}$.

\section{A. Prototype Design}

The prototype design is shown in in Fig. 2. The ultrasonic sensor functions to measure a water level, and will send input to the NodeMCU so that it can send a signal to the OLED screen and send notifications to the Telegram application, such as a water level and altitude status. NodeMCU also processes the data received, so that it can determine level of opening the floodgate.

The motor on the floodgate functions as a gate driver to move up or down, adjusting the command from the NodeMCU which previously got the output value from the water level read by the ultrasonic sensor. When the sensor reads the water level has reached $11 \mathrm{~cm}$ or more, the buzzer will light up and indicate a danger status.

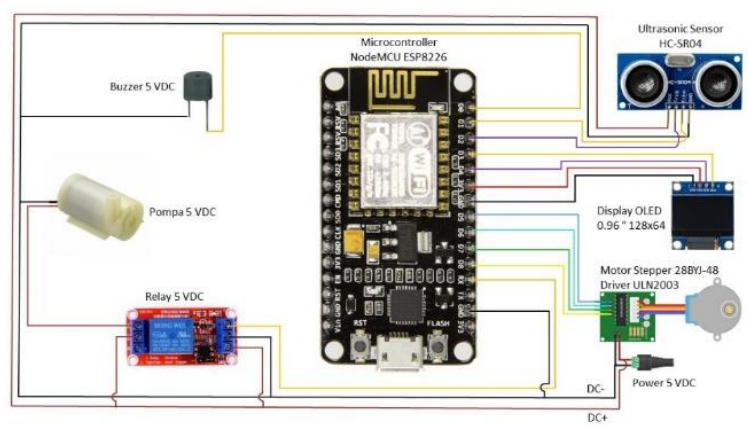

Fig. 2. Component circuit design

\section{RESULTS AND DISCUSSION}

\section{A. Prototype Testing}

Testing on the prototype is doing to find out whether the hardware or software can work in accordance with the planning of this research. Prototype testing is also useful for knowing the level of performance of the prototype function, so that all deficiencies and risks in the tool can be minimized so that the design of the tool can actually function effectively and be useful when implemented in the field.

\begin{tabular}{|c|c|c|c|}
\hline \multirow{2}{*}{$\begin{array}{l}\text { Actual Distance } \\
\text { Water Level } \\
(\mathrm{cm})\end{array}$} & \multirow{2}{*}{$\begin{array}{c}\text { Distance On } \\
\text { The OLED } \\
(\mathrm{cm})\end{array}$} & \multicolumn{2}{|c|}{ Error } \\
\hline & & $(\mathrm{cm})$ & $(\%)$ \\
\hline 5.5 & 5 & 0.5 & $9.0909 \%$ \\
\hline 6 & 6 & 0 & $0.0000 \%$ \\
\hline 6.5 & 6 & 0.5 & $7.6923 \%$ \\
\hline 7 & 7 & 0 & $0.0000 \%$ \\
\hline 7.5 & 7 & 0.5 & $6.6667 \%$ \\
\hline 8 & 8 & 0 & $0.0000 \%$ \\
\hline 8.5 & 8 & 0.5 & $5.8824 \%$ \\
\hline 9 & 9 & 0 & $0.0000 \%$ \\
\hline 9.5 & 10 & 0.5 & $5.2632 \%$ \\
\hline 10 & 10 & 0 & $0.0000 \%$ \\
\hline 10.5 & 11 & 0.5 & $4.7619 \%$ \\
\hline 11 & 11 & 0 & $0.0000 \%$ \\
\hline 11.5 & 11 & 0.5 & $4.3478 \%$ \\
\hline 12 & 12 & 0 & $0.0000 \%$ \\
\hline 12.5 & 13 & 0.5 & $4.0000 \%$ \\
\hline 13 & 13 & 0 & $0.0000 \%$ \\
\hline \multicolumn{3}{|c|}{ Error Mean } & $3.1803 \%$ \\
\hline
\end{tabular}

Based on the Table 3, when the water level has detected, starting from a level of $1 \mathrm{~cm}$ up to level of $13 \mathrm{~cm}$, overall the value that appears on the OLED indicator screen has a difference in accuracy of an average of $3.1803 \%$ error.

TABLE III. Ultrasonic SENSOR TESTING 


\section{B. Notification Telegram Testing}

This step is a testing the results of notifications about the status and water level via Telegram application. In this prototype design, the telegram notice will send notifications through the group so that all residents can monitor the water level with their smartphones wherever and whenever.

Test of the result this a quite important, considering that all the output results produced by this floodgate controller will affect the information obtained by residents who live around the river, so that residents and stakeholders can take effective steps in flood prevention and early response steps to minimize the risk of flooding. The test results:

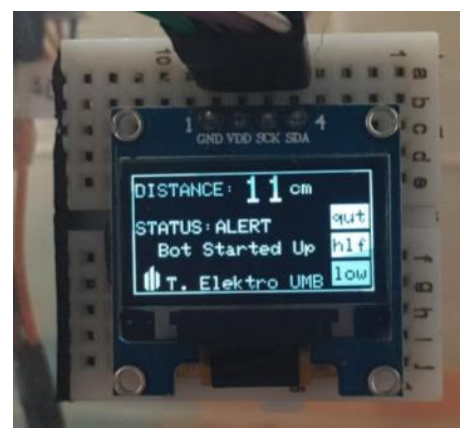

Fig. 3. Results on the OLED screen

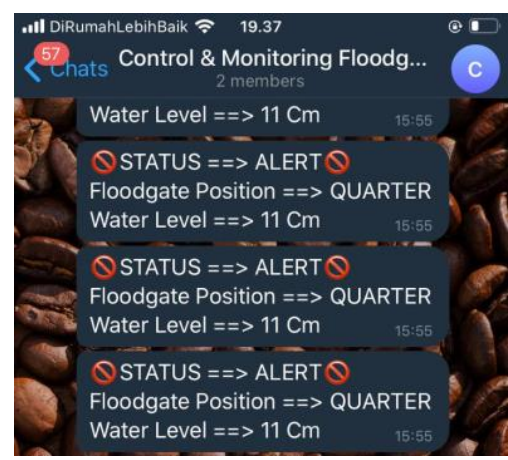

Fig. 4. Results on the notifications telegram

Fig. 4 is showing the status and water level on the OLED screen are same as that appears on the telegram notification, which is $11 \mathrm{~cm}$. At this altitude the status showed "ALERT", so that through this notification the residents get information that the water level on the river is quite high.

\section{Fuzzy Analysis}

As the author has previously described, this research using Sugeno-type fuzzy test, which uses the "weighted average" mathematical formula. The author chose the calculation of fuzzy logic using the weighted average formula because the formula is very easy to apply, so there is no need to use mathematical software such as Matlab or etc. All test data using the weighted average formula have been obtained in Table 4.

Based on the Table 4, the results show that there is a difference between increase of the sluice gate with the calculation using the weighted average formula. The average error is taken at each height level, the difference between the actual calculation using the fuzzy method is $9 \%$ error. According to the author's opinion, this occurs due to the unstable flow of the electric current at the MCU node so that it affects the stability of the electric current received on the stepper motor components.

TABLE IV. RESULTS OF THE COMPARISON OF PROTOTYPE WITH FUZZY ANALYSIS

\begin{tabular}{|c|c|c|c|c|}
\hline Water & Floodgate & Fuzzy Logic & \multicolumn{2}{|c|}{ Error } \\
\cline { 4 - 5 } Level & Altitude $(\mathbf{c m})$ & Testing $(\mathbf{c m})$ & $(\mathbf{c m})$ & $(\%)$ \\
\hline $6 \mathrm{~cm}$ & 0.5 & 0.3333 & 0.1667 & $33 \%$ \\
\hline $7 \mathrm{~cm}$ & 1 & 1 & 0 & $0 \%$ \\
\hline $8 \mathrm{~cm}$ & 1.5 & 1.6667 & 0.1667 & $11 \%$ \\
\hline $9 \mathrm{~cm}$ & 2 & 2.3333 & 0.3333 & $17 \%$ \\
\hline $10 \mathrm{~cm}$ & 3 & 3 & 0 & $0 \%$ \\
\hline $11 \mathrm{~cm}$ & 3.5 & 3.6667 & 0.1667 & $5 \%$ \\
\hline $12 \mathrm{~cm}$ & 4 & 4.3333 & 0.3333 & $8 \%$ \\
\hline $13 \mathrm{~cm}$ & 5 & 5 & 0 & $0 \%$ \\
\hline
\end{tabular}

\section{CONCLUSION}

The NodeMCU microcontroller is used as a component to process data from the system which functions to receive output and send commands to the stepper motor so that it can open the floodgates automatically by adjusting the water level. Based on the Table 4, it can be concluded that the test using the fuzzy method is the result of the height of the increase in the sluice gate obtained when testing has an average error difference of $9 \%$.

IoT-based notifications through the Telegram application are useful for make it easier for residents around the river to get actual information. So that residents and stakeholders around can take effective steps in flood prevention and early handling steps to minimize the risk of flood disasters.

To develop this research, in order to be more effective when implemented in the field, the selection of components on the tool needs to be improved and developed with a sensor to detect rainfall levels, so that the command generated for the floodgate is more accurate and effective.

\section{REFERENCES}

[1] A. Arjianto, "Rancang Bangun Model Mekanisme Buka-Tutup Pintu Air Otomatis," Universitas Muhammadiyah Surakarta, 2004.

[2] L. S. Vamvakeridou-Lyroudia et al., "Assessing and visualising hazard impacts to enhance the resilience of Critical Infrastructures to urban flooding," Science of the Total Environment, 2020, doi: 10.1016/j.scitotenv.2019.136078.

[3] M. Pregnolato, A. Ford, S. M. Wilkinson, and R. J. Dawson, "The impact of flooding on road transport: A depth-disruption function," Transportation Research Part D: Transport and Environment, 2017, doi: $10.1016 /$ j.trd.2017.06.020.

[4] M. Pregnolato, A. Ford, V. Glenis, S. Wilkinson, and R. Dawson, "Impact of Climate Change on Disruption to Urban Transport Networks from Pluvial Flooding," Journal of Infrastructure Systems, 2017, doi: 10.1061/(asce)is.1943-555x.0000372.

[5] D. Arif and B. Suprianto, "Rancang Bangun Kendali Level Air Otomatis Pada Tangki Dengan Servo Valve Berbasis Fuzzy Logic Controller Menggunakan Arduino," Jurnal Teknik Elektro, vol. 8, no. 1, 2019.

[6] R. A. Mel, D. P. Viero, L. Carniello, and L. D’Alpaos, “Optimal floodgate operation for river flood management: The case study of Padova (Italy)," Journal of Hydrology: Regional Studies, 2020, doi: 10.1016/j.ejrh.2020.100702.

[7] Fahruddin, "Sistem Pemantau dan Kendali Pintu Air Otomatis," 
Universitas Islam Negeri Makassar, 2014.

[8] I. A. Guna, "Sistem Monitoring Penetasan Telur Penyu Menggunakan Mikrokontroller NodeMCU Esp8266 Dan Protocol MQTT Dengan Notifikasi Berbasis Telegram Messenger," $J$ COSINE, vol. 2, no. 2, 2018

[9] Y. Saragih, J. H. Prima Silaban, H. Aliya Roostiani, and A. S. Elisabet, "Design of Automatic Water Flood Control and Monitoring Systems in Reservoirs Based on Internet of Things (IoT)," 2020, doi: 10.1109/MECnIT48290.2020.9166593.

[10] F. Hendajani, "Visualisasi Pintu Air Otomatis Menggunakan Sensor Ultrasonik Memanfaatkan NUVUTON NUC140VE3CN," STMIK Jakarta, 2017.

[11] T. Mantoro and W. Istiono, "Saving water with water level detection in a smart home bathtub using ultrasonic sensor and Fuzzy logic," 2018, doi: 10.1109/IAC.2017.8280602.

[12] R. E. Bellman and L. A. Zadeh, "Decision-Making In A Fuzzy Environment Report No ERL-69-8 National Aeronautics And Space Administration," 1970.

[13] L. A. Zadeh, "Fuzzy Sets," Information and Control, vol. 8, pp. 338-353, 1965.

[14] L. A. Zadeh, "The Concept of a Linguistic Variable and its Application to Approximate Reasoning," Information Sciences, vol. 8, 1975 .

[15] Q. Song and B. S. Chissom, "Forecasting enrollments with fuzzy time series - Part I," Forecasting enrollments with fuzzy time series part II, vol. 62, no. 1, pp. 1-8, 1994, doi: 10.1016/01650114(93)90355-L.

[16] S.-M. Chen, "Fuzzy forecasting with DNA computing," Forecasting enrollments based on fuzzy time series, vol. 81, pp. 311-319, 1996, doi: 10.1007/11925903_25.

[17] H. Liu, X. Deng, and W. Jiang, "Risk evaluation in failure mode and effects analysis using fuzzy measure and fuzzy integral," Symmetry, 2017, doi: 10.3390/sym9080162.

[18] J.-S. R. Jang, C.-T. Sun, and E. Mizutani, Neuro-Fuzzy and Soft Computing A Computational Approach to Learning and Machine Intelligence. Prentice Hall, 1997.

[19] C.-L. HWANG, Y.-J. LAI, and T.-Y. LIU, "A New Approach For Multiple Objective," Computers Ops Res. Vol. 20, vol. 20, no. 8, pp. 889-899, 1993.

[20] A. Firdausi, I. R. F. Arif, and G. P. N. Hakim, "Time Control Nebulizer Operation Using Fuzzy Sugeno Method," Journal of Robotics and Control (JRC), 2021, doi: 10.18196/jrc.2259.

[21] N. Wulandari and A. G. Abdullah, "Design and Simulation of Washing Machine using Fuzzy Logic Controller (FLC)," IOP Conference Series: Materials Science and Engineering, vol. 384, no. 1, 2018, doi: 10.1088/1757-899X/384/1/012044.

[22] Mardlijah, A. Mahatir Najar, and D. Khusnul Arif, "Comparison between PID controller and fuzzy sliding mode control (FSMC) on super heater system," Journal of Physics: Conference Series, vol. 1218, no. 1, 2019, doi: 10.1088/1742-6596/1218/1/012055.

[23] E. K. Zavadskas, J. Antucheviciene, and P. Chatterjee, Multiplecriteria decision-making (MCDM) techniques for business processes information management, vol. 10, no. 1. 2018.

[24] D. Arini, "Analisis Pemilihan Vendor Dengan Menggunakan Pendekatan Metode Fuzzy Topsis Di Pt. Tripatra Engineers And Constructors," Jurnal Ilmiah Teknik Industri, vol. 3, no. 1, pp. 53$58,2015$.

[25] D. Septiyana and G. P. N. Hakim, "Penerapan Fuzzy Topsis Untuk Pemilihan Pemasok Pada Manajemen Rantai Pasok Di Pt Aetra Tangerang," Journal of Industrial Manufacturing, vol. 3, no. 2, 2018 .

[26] G. P. N. Hakim, A. Firdausi, M. Alaydrus, and S. Budiyanto, "Dynamic Traffic Light Timing Control System using Fuzzy TOPSIS Algorithm," 2018.

[27] T. Widianti and H. Firdaus, "Pengujian Suhu Lemari Es Dengan Metode Terintegrasi Fuzzyfailure Mode and Effect Analysis (FuzzyFmea)," Jurnal Standardisasi, vol. 18, no. 1, p. 9, 2018, doi: 10.31153/js.v18i1.693.

[28] E. Adar, M. Ince, B. Karatop, and M. S. Bilgili, "The risk analysis by failure mode and effect analysis (FMEA) and fuzzy-FMEA of supercritical water gasification system used in the sewage sludge treatment," Journal of Environmental Chemical Engineering, 2017, doi: 10.1016/j.jece.2017.02.006.

[29] T. Immawan, W. Sutrisno, and A. K. Rachman, "Operational risk analysis with Fuzzy FMEA (Failure Mode and Effect Analysis) approach (Case study: Optimus Creative Bandung)," MATEC Web of Conferences, vol. 154, 2018, doi:
$10.1051 /$ matecconf $/ 201815401084$

[30] S. B. Karwade and M. S. Ali, "Review Paper on Load Forecasting Using Neuro Fuzzy System," IOSR Journal of Electrical and Electronics Engineering, vol. 10, no. 3, pp. 38-42, 2015, doi: 10.9790/1676-10323842.

[31] E. Safwani, A. Firdausi, and G. Hakim, "Tower Planning And Arrangements Mobile Telecommunication District Central Aceh With Methode Fuzzy Clustering," Journal of Robotics and Control (JRC), 2020, doi: 10.18196/jrc.2144.

[32] Y. Feng, H. Lu, W. Xie, H. Yin, and J. Bai, “An Improved Fuzzy CMeans Clustering Algorithm Based on Multi-chain Quantum Bee Colony Optimization," Wireless Personal Communications, vol. 102, no. 2, pp. 1421-1441, 2018, doi: 10.1007/s11277-017-5203-2.

[33] G. P. N. Hakim, A. Firdausi, and M. Hafidz, "Wireless Sensor Network Routing Using Fuzzy Topsis Algorithm to Provide Best Path Quality of Service," Technology Reports of Kansai University, vol. 62 , no. 5,2020 .

[34] S. K. S. L. Preeth, R. Dhanalakshmi, R. Kumar, and P. M. Shakeel, "An adaptive fuzzy rule based energy efficient clustering and immune-inspired routing protocol for WSN-assisted IoT system," Journal of Ambient Intelligence and Humanized Computing, 2018, doi: 10.1007/s12652-018-1154-z. 